\title{
HEALTH AND EDUCATION IN ROMA FAMILIES. COMPARATIVE STUDY, ROMANIAN ROMA FAMILIES FROM RENNES, FRANCE VS. ROMA FROM MIRONU, SUCEAVA, ROMANIA
}

\author{
Lecturer dr. Daniel Lucheș ${ }^{1}$ \\ Lecturer dr. Despina Vasilcu ${ }^{2}$ \\ PhD student Ionela Gălbău ${ }^{3}$ \\ ${ }^{1}$ West University of Timişoara, Romania \\ ${ }^{2,3}$ Ştefan cel Mare University, Suceava, Romania \\ (C) 2016 Daniel Lucheș, Despina Vasilcu, Ionela Gălbău \\ This is an open access article distributed under the Creative Commons Attribution-NonCommercial-NoDerivs license \\ (http://creativecommons.org/licenses/by-nc-nd/3.0/) \\ DOI: $10.1515 /$ eras-2016-0005
}

\begin{abstract}
The lower level of education for health and school education among vulnerable groups from Romania is an important part of the vicious circle of poverty and social removal, in particular for Roma minority. The quality of education and health related to this minority group is correlated with cultural aspects and the Roma attitude toward those determinants factors.

The study relies on data obtained after questioning a number of 50 people, Roma that immigrated in Rennes, France and 50 Roma from Mironu, Valea Moldovei County, Suceava city. The results of the research show a considerable difference between the attitude of the Roma people from France compared with the attitude of the Romas from Romania regarding the health services and the education that they benefit. The immigrants have a positive attitude regarding the school and the medical services, after applying the quiz it can be said that they are pretty unpleased of the Romanian services than the foreign ones.

Although, the Roma minority has the support of the authorities in Rennes and also in Mironu, support for social inclusion and adaptation in a local community, but they are reluctant in accepting these benefits. The programs developed for helping them hadn't had the expected results, though.

Health and education have a specific purpose in developing the society in general. Now we can say that solving the problem with the access to education and health for Roma minority represents the key of their social and economic integration.
\end{abstract}

Keywords: vulnerable groups, Roma minority, health and education, immigrants

\section{Introduction}

Health and Education are two essential components in the analysis of vulnerable groups of the population in Romania, in which it is to be credited and Roma population. Damage to the standard of living, accentuating the poverty, the discrimination of the social and economic situation, to which shall be added the cultural and behavioural specific to this ethnic groups are factors that limited access to public services - in particular to the health and education (Stewart, 1997; Bouillon, 2009).

Numerous actions were initiated at the global and European level through which the countries concerned have declared the political will to fight against discrimination against Roma, of social exclusion and poverty which affect them. In this respect, the Decade of Roma (2005-2015) is an international initiative which was focused on the governments, nongovernmental organizations and civil organizations of Roma in the direction of solving the 
problems related to the education, health, stimulated to enter the labour market and habitable, the actions carried out in the course of this decade having as the main aim of reducing the split ratio between the Roma population and non-Roma, by granting scholarships, carrying out of training programs and actions in the direction of the reform of the education.

Inequality of access to education is a major problem in all the countries participating in the "Roma Decade", presented data indicating that most of the children of Roma are educated later and the rate of school abandonment is very high. In Romania, according to the study "The State of the world's children, carried out by UNICEF, in 2016, one in five children aged between 15 and 18 years, which do not go to school is of Roma (UNICEF, 2016). If health is essential for the maintenance of life, education is key to the integration of the Roma in society, its absence having regard the significance of a future without hope of a normal life.

The reduced rate the schooling of Roma is a determining factor which explains the low insertion on the labour market, marginalisation and systematic exclusion from society, which may cause later problems and the more serious the related to the juvenile and crime (Kropp, 2012).

Together with the education, health Roma represents a major concern at the European level. A report of the European Commission, published in 2014, indicates that the Roma people, in general, have a poor health, as compared with the European average and a life expectancy of more reduced compared with that of the population non-Roma.

According to the same sources, the mortality rate among the Roma population in Romania is $1.83 \%$ higher than that recorded in the population of the non-Roma, and maternal mortality is 15 times higher than that of the rest of the population (European Commission, 2014). According to a study published by the Institute for Public Policies (IPP) in the year 2015 , almost $46 \%$ of the total of the children of Roma do not benefit from free vaccination granted by the Ministry of Health, either because the refusal of vaccination, either because of the lack of information/education or because of the deficiencies in the services of primary health, while the vaccination rate exceeds $95 \%$ in the general population (IPP, 2015).

Emigration does not contribute to improving the state of health of migrants from Roma and sometimes make impossible their access to health care services for the fact that many of them do not have the official acts, may not be the proof of the right of property and are not recognized as nationals of the country in which they live (Marušiakova \& Popov, 2008). The situation of children in the Roma families who have emigrated is sometimes difficult, both from the perspective of the "invisible children ", who were born abroad and do not have identity papers, and from the point of view of children who interrupt a diagram of treatment as a result of the Migration (Gugliemo, 2004; Nacu, 2010). The situation of the Roma minors which follows the migration trajectory of parents implies the abandonment of school or even ruled courses, and entry and attendance at international schools under the conditions made the language of the country of destination shall be proved a process extremely difficult, which in the majority of cases aimed at increasing illiteracy throughout the Roma row (Liégeois, 2009; Gălbău \& Vasilcu 2015).

The aim of this article consists in the demonstration of the role of immigration in the meaning of the change of the Roma mentality, of their attitude toward the education and concern for the health status and personal and family life. Comparison of the results obtained from the investigation carried out in the framework of both Roma communities, in France and in Romania, shows that the involvement of the decision-makers and the local players in order to access the Roma population to health education and contribute to the awareness of the populations in difficulty, a path that is important in the settlement of the positive terminal of the problems faced by this minority. 


\section{Materials and methods}

The examination has assumed the application of a number of 100 questionnaires in localities Rennes in France and Mironu, common Valea Moldovei, Romania. The data were taken from the health care units and high schools in the two localities and the nongovernmental organisation MRAP (Movement Against Racism and for Friendship between Peoples) of Rennes, an organisation that deals with the support of the communities of emigrants from the area of the region.

Subsequently, the data base has been processed in SPSS (Statistical Package for the Social Sciences) and using Microsoft Office/Excel/Date Analyses.

\section{Results and discussions}

Although the access to health and education are fundamental rights of each individual, the Roma minority is facing major difficulties with regard to access to these public services.

The attitude toward the medicine and school, sometimes the refusal to appeal to these services can be explained on the one hand, by the lack of information, the lack of medical infrastructure and school and of the channels of communication (in the locality Mironu pursues his activity a single health mediator under the conditions in which the number of the Roma is approximately 1,800 persons and the school is closest to a distance of $5 \mathrm{~km}$ ), and on the other hand, by cultural beliefs and traditional practices of the Roma.

From the data obtained from the medical units and high schools in the two localities (Primary School of the public Chantepie-Rennes and School from Valea Moldovei), it appears that the Roma people have a satisfactory frequency (Figure.1) as regards access to education (to Primary School of Chantepie-Rennes entered 15 pupils, all regularly attending courses, and their parents are directly involved in the activities of the teaching staff), and a more accessibility reduced to medical services in both Rennes and Mironu.

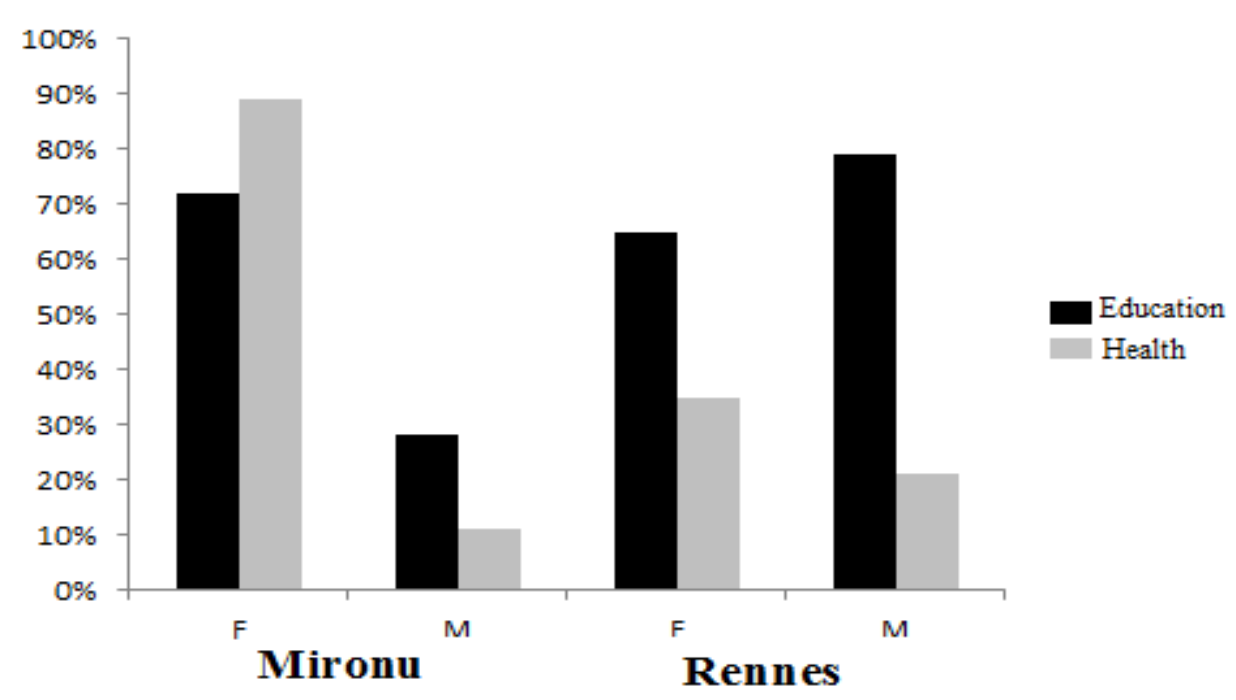

Figure1. The frequency of accessing the services of health and education of Roma from Rennes and Mironu 
One of the objectives of this article consists in the demonstration of Roma attitude toward the health and education and the capture of changes in positive behavioural plan as a result of the emigration.

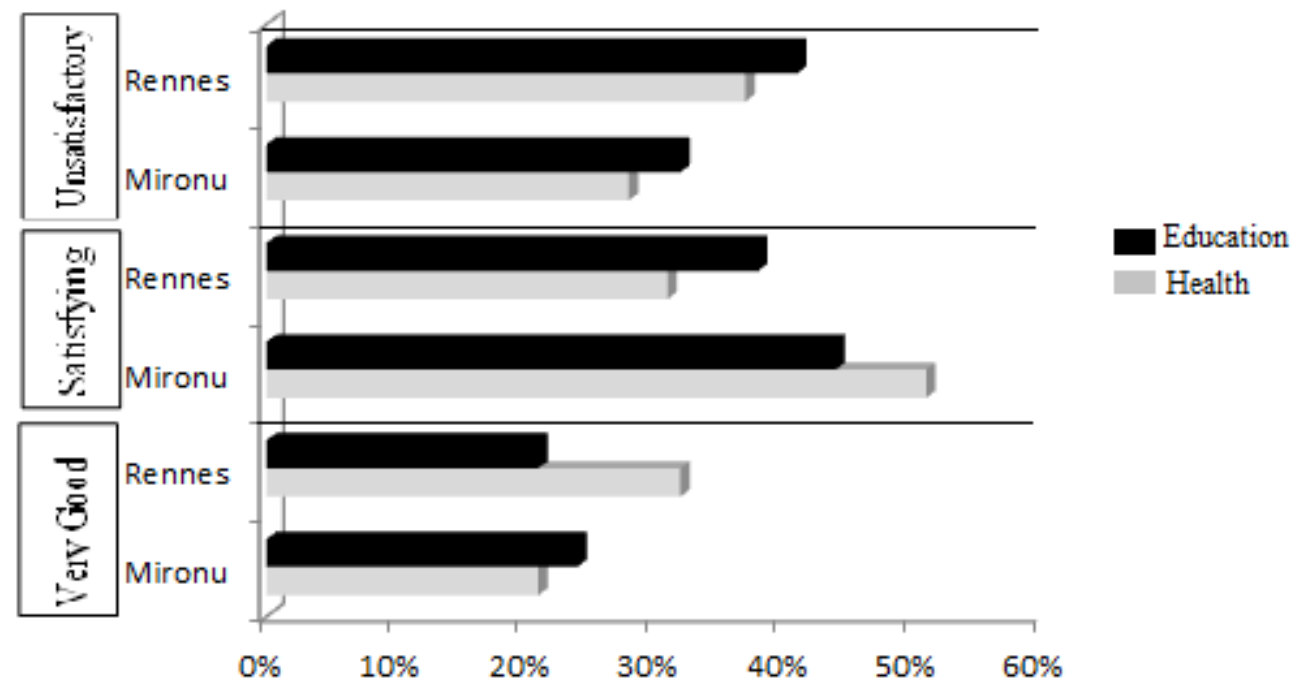

Figure2. The perception of Roma people from Rennes and Mironu with regard to medical services and educational

In Figure 2. it can be seen that both the Roma people from Rennes and those of Mironu, have a satisfactory attitude toward the health and education.

It is found, however, that in the case of the community of Roma from Rennes, health levy is better than those of Mironu; the French health mediator weekly visits the Roma families and the non-governmental organisation MRAP (Movement Against Racism and for Friendship between Peoples) supports their access to quality medical services. The differences of perception between the two communities are due to the active involvement of the French society and of the state institutions in supporting minorities and facilitating their access to different services.

The satisfactory perception to the school of Roma from both Rennes and Mironu is the consequence of the implementation of programs to stimulate the Roma people in order to facilitate the integration of the Roma students in the communities where they study.

The School of Chantepie-Rennes is a joint venture where studying both students of nationality as far as the French and students of other nationalities (Roma people of Romanian nationality, Syrians, Indians) and in the school from Valea Moldovei the proportion of a larger holding the Romanian students.

The results of the investigation indicate that the perception of education is closely linked to the level of training of the Roma.

In order to determine whether the series between the perception of the school and the level of education of Roma people is there any resemblance, I used the ANOVA Method. The value of the significance $F$, equal to 3.98 and less than $p$-value 0.7089 suggested deciding that the level of training influences the perception toward the education of Roma people from the two localities analysed. 


\begin{tabular}{|c|c|c|c|c|c|c|c|c|c|}
\hline ANOVA & $\begin{array}{l}\text { Column } 1 \\
d f\end{array}$ & \multicolumn{2}{|c|}{ Column 2} & \multicolumn{2}{|c|}{ Column 3} & \multicolumn{2}{|c|}{ Column 4} & \multicolumn{2}{|l|}{ Column 5} \\
\hline Regression & 1 & 19247.22 & 64 & 19247.2 & & 30. & 18 & $3.98 \mathrm{E}-05$ & \\
\hline Residual & 98 & 10723.9 & 15 & 636.701 & & & & & \\
\hline Total & 100 & 30191.15 & 789 & & & & & & \\
\hline Column1 & Coefficients & Standard Error & t Stat & P-value & & & $\begin{array}{c}\text { Upper } \\
95 \%\end{array}$ & $\begin{array}{l}\text { Lower } \\
95.0 \%\end{array}$ & $\begin{array}{l}\text { Upper } \\
95.0 \%\end{array}$ \\
\hline Intercept & 3.791 & 8.4649 & .3933 & 0.7089 & -15 & & 20.3139 & -15.6359 & 20.3139 \\
\hline 100 & 0.9469 & 0.1717 & 5.5152 & $3.98 \mathrm{E}-05$ & 0.5 & & 1.3092 & 0.5847 & 1.3092 \\
\hline
\end{tabular}

Table 1. ANOVA Method

As can be seen in Table 2. the number of Roma people with medical problems is in a continuing increase; at the same time worrying is the fact that in both localities, the data obtained from the posts do not coincide with those in the field. The feature is the presence of a disease characteristic of the social groups less-favoured areas, respectively within higher dermatological diseases and respiratory, classified as a general rule, as poverty diseases.

\begin{tabular}{|c|c|c|c|c|c|c|c|c|}
\hline \multirow{2}{*}{$\begin{array}{l}\text { Diseases/ } \\
\text { Years }\end{array}$} & \multicolumn{2}{|c|}{$\begin{array}{l}\text { Dermatological } \\
\text { diseases }\end{array}$} & \multicolumn{2}{|c|}{$\begin{array}{l}\text { Pneumology } \\
\text { diseases }\end{array}$} & \multicolumn{2}{|c|}{ Heart disease } & \multicolumn{2}{|c|}{$\begin{array}{l}\text { Respiratory } \\
\text { diseases }\end{array}$} \\
\hline & Rennes & Mironu & Rennes & Mironu & Rennes & Mironu & Rennes & Mironu \\
\hline 2012 & 5 & 9 & 2 & 2 & 1 & 5 & 14 & 22 \\
\hline 2013 & 7 & 8 & 4 & 3 & 1 & 5 & 14 & 20 \\
\hline 2014 & 5 & 10 & 3 & 1 & 1 & 8 & 15 & 21 \\
\hline 2015 & 8 & 12 & 5 & 5 & 2 & 8 & 22 & 24 \\
\hline
\end{tabular}

Table 2. The number of Roma people with medical problems of Rennes and Mironu

For the interpretation of the data we used SPSS programs (Statistical Package for the Social Sciences) and Microsoft Office/Excel/Date Analyses.

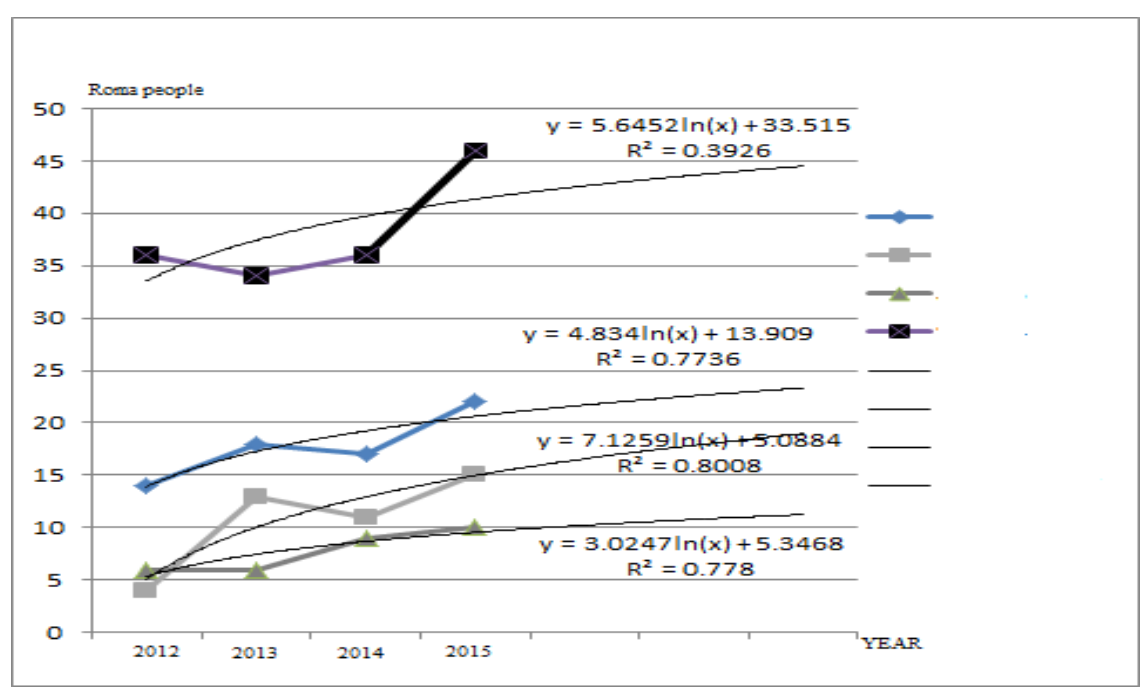

Figure 3. The evolution of Roma diseases 
By extrapolation, we obtained an index y for the diseases which have come forward with the highest intensity in Roma population analysed during the period 2012-2015-, pathologies which have been referred to by the participants in the investigation. The coefficients $\mathrm{R}^{2}$ between 0.396 (Roma dermatological diseases) and 0.8008 (Roma respiratory diseases), which shows that the number of Roma people with health problems will register a significant increase in the following period,

Surprisingly, the results of the analysis on which we have made a reveals that the Roma concern for education is greater compared with that for health. Positive perception in relation to the education is strongly influenced by the involvement of the authorities by programs to support the minorities.

Cultural models specific to each community are also important factors which decide the attitude of the Roma. The history of the Roma proves that due to their cultural traits, nonintegral in society ownership, they replied by the refusal of the integration of both the social pressures and to any mode of support or incentive to minorities.

A different vision of Roma from Rennes compared with those in Mironu with regard to services of health and education is due to an important involvement of NGO-s for integrating the ethnic minorities.

MRAP (Movement Against Racism and for Friendship between Peoples) offers support of the Roma community starting with 2011 when they arrived in Rennes, by providing them with the dwelling and by ensuring access to education by entry of the children to schools nearby (School of Chantepie and School of Saint-Gregoire) and the inclusion of all persons in a medical unit located in the vicinity.

At the same time, local authorities have facilitated consultation of the Roma by specialists in order to diagnose the correct and appropriate treatment. However, both the NGO-s and local authorities are often confronted with the refusal of minority population to benefit from such services.

In the framework of the Roma community in the Mironu (the largest community of Roma in Suceava County) operate two mediators, one school mediator and other health care mediator, which from the point of view of the inhabitants, fail to cope with daily problems signalled by them.

In view of a large number of Roma (1800 persons), the health mediator fails to centralise information about each person and then appear discrepancies between the statistical data provided by the posts and those collected on the ground in the questionnaires.

The relationship with the school mediator, in exchange, is good, Roma students have a good frequency at the level of the gymnasium only that parents are weakly involved in school activity and poorly informed as to the ability to continue their studies at a higher level.

\section{Conclusion}

The conditions of life under the standard affect many times the health status and the level of educational attainment of the Roma communities both in the country and of the Roma of Romanian nationality from abroad.

The problem of education and health of the population of the Roma takes multiple facets and understanding and resolving it involves the analysis in the context of the socioeconomic situation and the specific cultural ethnic Rome.

The protection of ethnic minorities means complying with their rights, especially of persons that and the development of active citizenship. A gang of action consists in the respect 
and to protecting the rights of Roma communities, especially in the field of education and health.

It is necessary to emphasise the determinants connected clients in the fields of health and education, including access to the labour market, housing, to health care and social assistance, highlighting once again the need for an integrated approach to improving the situation of the Roma.

\section{References}

Bouillon, F., (2009). Les Mondes du Squat. Anthropologie d'un Habitat Précaire, Paris, Monde/PUF.

European Commission, (2014), Roma Health Report Health status of the Roma population. Data collection in the Member States of the European http://ec.europa.eu/employment_social/publications/2005/ke6204389_fr.pdf, [Accessed 25.09.2015]

Gălbău, I. \&Vasilcu, D., (2015). The Effects of Parent's Migration on the School Activity of Roma Pupils. Case Study: Suceava, SGEM 2015, Conference Proceedings, pp.959-966.

Gugliemo, R., (2004), Human Rights in the Accession Process: Roma and Muslims in an Enlarging Europe, Minority Protection and the Enlarged European Union: The Way Forward, Local Government and Public Service Reform Initiative, Open Society Institute, pp. 37-59.

Institutul pentru Politici Publice, Bucuresti, (2015). Accesul Echitabil al Copiilor Romi la Serviciile de Sanatate, http:/www.cjgiurgiu.ro/portal/giurgiu/cj/portal.nsf/0/F971A5F0A1D7B9EEC2257E610040F2D6/\$FILE/IP P_Studiu_Accesul-la-servicii-de-sanatate_PEH-009.pdf, [Accessed 25.06.2016]

Kropp,M., (2012), La Migration des Roms au Sein de l'Union Européenne-Une Minorité Ethnique est Devenue la « patate chaude » de la Politique Européenne, Bruxelles,.

Liégeois, J.-P., (2009). Roms et Tsiganes, Paris, La Découverte, p.125.

Marušiakova, E. \& Popov, V., (2008). Les Migrations des Roms Balkaniques en Europe Occidentale: Mobilités Passes et Présentes, Balkanologie, Vol. XI, no 1-2. [Accessed 14.04.2015], http://balkanologie.revues.org/972

Nacu, A., (2010). Les Roms Migrants en Region Parisienne: les Dispositifs d'une Marginalization, Revue européenne des migrations, vol 26.

Stewart, M., (1997), The Time of the Gypsies, Boulder, Westview Press, p.302

UNICEF, (2016). The State of the http://www.unicef.org/publications/files/UNICEF_SOWC_2016.pdf

world's children, 